Utah State University

DigitalCommons@USU

\title{
Participation Decisions, Angler Welfare, and the Regional Economic Impact of Sportfishing
}

\author{
Keith R. Criddle \\ Utah State University \\ Mark Herrmann \\ S. Todd Lee \\ Charles Hamel
}

Follow this and additional works at: https://digitalcommons.usu.edu/eri

\section{Recommended Citation}

Criddle, Keith R.; Herrmann, Mark; Lee, S. Todd; and Hamel, Charles, "Participation Decisions, Angler Welfare, and the Regional Economic Impact of Sportfishing" (2001). Economic Research Institute Study Papers. Paper 226.

https://digitalcommons.usu.edu/eri/226

This Article is brought to you for free and open access by the Economics and Finance at DigitalCommons@USU. It has been accepted for inclusion in Economic Research Institute Study Papers by an authorized administrator of DigitalCommons@USU. For more information, please contact digitalcommons@usu.edu.

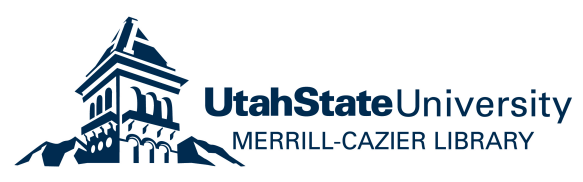


Economic Research Institute Study Paper

ERI \#2001-13

PARTICIPATION DECISIONS, ANGLER WELFARE, AND THE

REGIONAL ECONOMIC IMPACT OF SPORTFISHING

by

KEITH R. CRIDDLE

Department of Economics

Utah State University

3530 Old Main Hill

Logan, UT 84322-3530

MARK HERRMANN

Department of Economics

University of Alaska Fairbanks

Fairbanks, AK 99775-6080

S. TODD LEE

National Marine Fisheries Service

Alaska Fishery Science Center

7600 Sand Point Way NE, Bldg 4

Seattle, WA 98115

CHARLES HAMEL

North Pacific Fishery Management Council

Anchorage, AK 99501-2252

May 2001 


\title{
PARTICIPATION DECISIONS, ANGLER WELFARE, AND THE \\ REGIONAL ECONOMIC IMPACT OF SPORTFISHING
}

\author{
Keith R. Criddle \\ Department of Economics \\ Utah State University \\ 3530 Old Main Hill \\ Logan, UT 84322-3530 \\ Mark Herrmann \\ Department of Economics \\ University of Alaska Fairbanks \\ Fairbanks, AK 99775-6080 \\ S. Todd Lee \\ National Marine Fisheries Service \\ Alaska Fishery Science Center \\ 7600 Sand Point Way NE, Bldg 4 \\ Seattle, WA 98115 \\ Charles Hamel \\ North Pacific Fishery Management Council \\ Anchorage, AK 99501-2252
}

The analyses and views reported in this paper are those of the author(s). They are not necessarily endorsed by the Department of Economics or by Utah State University.

Utah State University is committed to the policy that all persons shall have equal access to its programs and employment without regard to race, color, creed, religion, national origin, sex, age, marital status, disability, public assistance status, veteran status, or sexual orientation.

Information on other titles in this series may be obtained from: Department of Economics, Utah State University, 3530 Old Main Hill, Logan, Utah 84322-3530.

Copyright (C) 2001 by Keith R. Criddle, Mark Herrmann, S. Todd Lee, and Charles Hamel. All rights reserved. Readers may make verbatim copies of this document for noncommercial purposes by any means, provided that this copyright notice appears on all such copies. 


\title{
PARTICIPATION DECISIONS, ANGLER WELFARE, AND THE REGIONAL ECONOMIC IMPACT OF SPORTFISHING

\author{
Keith R. Criddle, Mark Herrmann, S. Todd Lee, Charles Hamel
}

\begin{abstract}
Data from a stated preference survey of anglers who fished in marine waters off the Kenai Peninsula, Alaska, are used to model angler participation, angler welfare, and regional economic activity. The probability of taking a sportfishing trip is represented as a nonlinear function of predictable or controllable trip attributes and demographic characteristics. Conditional individual probabilities are aggregated into estimates of total recreation demand and compensating variation using a simulation-based sample enumeration, weighted to reflect differences in participant motivation. A regionally adjusted zip code-level input-output model is used to represent the level of primary and secondary expenditures conditioned on participation. This approach results in a behaviorally based integrated model for exploring the changes in angler welfare and regional economic activity occasioned by changes in the demand for sportfishing that arise from changes in trip costs or the expected number, size, or mix of species caught. Because the model allows for nonlinear marginal utility, and substitution and complementary effects across attributes, participation rates, angler welfare, and the magnitude of regional economic activities exhibit nonlinear responses to variations in trip attributes.
\end{abstract}

Key words: recreational demand, angler welfare, regional economic impacts 


\title{
PARTICIPATION DECISIONS, ANGLER WELFARE, AND THE
}

\author{
REGIONAL ECONOMIC IMPACT OF SPORTFISHING*
}

\section{Introduction}

The marine sport fisheries of Lower and Central Cook Inlet, Alaska (Figure 1), support a large recreation based economic sector that provides non-monetary benefits to participants and pecuniary benefits to businesses and residents of the Kenai Peninsula region. Although this study focuses on the region's most important saltwater sports fishery, the fishery for Pacific halibut (Hippoglosus stenolepis), the marine sport fisheries for chinook (Oncorhynchus tshawytscha) and coho (O. kisutch) are treated as potential substitutes and complements for the halibut sport fishery.

Pacific halibut are managed by an international agreement between the United States and Canada. Under the auspices of this agreement, the International Pacific Halibut Commission (IPHC) establishes constant exploitation yield (CEY) based harvest limits in the eastern North Pacific, Gulf of Alaska, and eastern Bering Sea. The authority to allocate catches among competing commercial, sport, and subsistence interests is delegated to the individual nations. The North Pacific Fishery Management Council (Council) is responsible for allocating halibut catches off Alaska. The commercial Total Allowable Catch (TAC) for Pacific halibut has been determined by subtracting a bycatch allowance and expected non-commercial (sport and subsistence) catches from the CEY-based harvest limit. However, as the share of halibut caught by sport fishers has increased, the Council has been lobbied to take actions to limit erosion of the commercial TAC. Growth of sportfishing catches has been particularly pronounced in the Central Gulf of Alaska Region (Prince William Sound, Resurrection Bay, Kodiak, Yakutat, and especially Cook Inlet and adjacent portions of the Gulf of Alaska) where sportfishing landings have grown from less than 2 percent of total removals (commercial, sport, and bycatch) in the late 1970s to over 18 percent in the mid-1990s.

\footnotetext{
*Keith R. Criddle is a professor in the Department of Economics at Utah State University, e-mail: kcriddle@econ.usu.edu. Mark Herrmann is a professor in the Department of Economics at the University of Alaska Fairbanks, e-mail: ffmlh@uaf.edu. S. Todd Lee is an Industry Economist at the Alaska Fisheries Science Center, National Marine Fisheries Service, e-mail: Todd.Lee@noaa.gov. Charles Hamel is a research associate in the Department of Economics at the University of Alaska Fairbanks, e-mail: ffcdh1@uaf.edu.

Partial funding for this project was provided by the University of Alaska Sea Grant College Program project 98-403 R14-17 and from the Mineral Management Service through the University of Alaska Coastal Marine Institute project 12-35-0001-30661 task order 14196. The views expressed herein are those of the authors and do not necessarily reflect those of their respective employers or the funding entities.
} 
During the same period, Alaska resident sportfishing license sales increased $41 \%$ (from about 122,000 to about 172,000 per year) and nonresident license sales increased $480 \%$ (from about 56,000 to about 269,000 per year). In response to the intensified allocation conflicts between commercial and sport interests, the Council approved a management structure that sets a guideline harvest level (GHL) or cap for charterboat-based sportfishing catches of halibut equal to the 1995-1999 average catch with provisions for a reduction in the GHL if stock biomass declines (NPFMC 2000). Under the GHL, subsistence harvests and harvests by sport fishers who do not hire charterboat services will continue to be deducted from the commercial TAC. If approved by the Secretary of Commerce, the GHL will be implemented in 2002. More recently, the Council has approved an individual fishing quota (IFQ) program for charter catches of halibut (NPFMC 2001). Under the proposed IFQ program, voluntary market transactions will allocate halibut within the charterboat sector and between commercial and charter operations. If approved by the Secretary of Commerce, the charter IFQ program will replace the GHL in 2003.

\section{The Data}

Data to support our analyses were obtained using a postal survey of 4,000 anglers who purchased an Alaskan license in 1997 (Herrmann et al. 2001b) and through onsite interviews conducted with local government officials and business community members (Herrmann et al. 2001a). The angler survey solicited demographic information, information about expenditures incurred during and attributes of recent sportfishing trips taken in Lower or Central Cook Inlet, and asked respondents to state their preferences with respect to hypothetical trips. The survey data were used to develop a statistical model of individual participation decisions. The model provided a basis for estimating total demand and angler net benefits. The interviews and secondary data were combined with information from the survey to update the input-output model technical coefficients and to disaggregate sportfishing from other sectors in the input-output model. The angler survey elicited an overall response rate of $70.08 \%$ on delivered surveys. Baseline estimates of total expenditures were calculated using information from the survey in combination with Alaska Department of Fish and Game (Howe et al. 1998) estimates of total angler days.

Survey respondents were asked to provide detailed information regarding expenses incurred on their most recent salmon and halibut fishing trips. These expenditures included transportation and lodging as well as fishing expenditures. Non-residents spent an average of $\$ 294.21$ per charter-based sportfishingday: $\$ 103.87$ in transportation and living expenses and $\$ 190.34$ in fishing expenses. Nonresident fishing expenditures included charter fees $(\$ 140.75)$ and fish processing charges $(\$ 32.72)$. Alaska residents from outside the Kenai Peninsula Borough spent an average of $\$ 204.91$ per charter-based sportfishing-day. Locals (Kenai Peninsula Borough residents) averaged \$167.47 in fishing expenditures per day of charterbased fishing. The average cost-per-day for charter-based sportfishing trips was $64 \%$ higher than the average for trips taken on private vessels.

The total number of angler-days fished in Lower and Central Cook Inlet during 1997 was 197,556 (Howe et al. 1998). The distribution of sportfishing effort across fishing modes and residency categories is reported in Table 1. In order to isolate the monetary effects of changes in participation in Lower and Central Cook Inlet marine sport fisheries, it is important to focus only on expenditures that are directly attributable to those fisheries. Because marine sportfishing was not a primary motivation for trips taken by some survey respondents, it would be inappropriate to attribute all of the trip expenses to the existence of marine sportfishing opportunities. Expenditure estimates were therefore adjusted downwards using data on trip purpose from the survey. The total spending directly attributable to the fishing component of trips taken in 1997 (i.e., money that would not have been spent if the fishing component was cancelled) was estimated to have been $\$ 34.1$ million, $\$ 28.5$ million of which was spent on the Kenai (Tables 2 and $3)$. Because it is assumed that local residents will substitute spending on other regional recreational activities for their foregone sportfishing expenditures, their expenditures ( $\$ 3.5$ million) were deducted. The $\$ 25.0$ million remainder reflects an infusion of spending on the Kenai Peninsula that would not have occurred in the absence of marine sportfishing opportunities in Lower and Central Cook Inlet (Table 4). 
The adjusted 1997 expenditure data were used as a baseline in the regional economic model described below.

\section{Individual Participation Decisions, Total Demand, and Angler Welfare}

Changes in fishery regulations, environmental quality, and resource abundance, as well as trip costs, can affect the expected net benefit associated with sportfishing, and therefore the decision to participate in (take) a sportfishing trip. Consequently, the ability to forecast changes in participation rates is important in many policy settings. Previous studies have used demographic characteristics to explain changes in the demand for recreational fishing (Holland and Ditton 1992, Aas 1995, Thunberg et al. 1999). The disadvantage of these models is that the resulting forecasts are conditional on conjectures about demographic change. That is, such models shift the focus from forecasting changes in participation to predicting demographic change. Moreover, demography-based participation models are not suitable for predicting changes in the demand for recreational fishing that might arise in response to changes in trip costs, fishing conditions, or management actions. Our approach avoids these problems by focusing on explanatory variables that are predictable or subject to direct control. Consequently, our model is better suited for policy evaluation and for forecasting participation rate responses to changes in trip costs and catch rates.

Survey respondents were presented a set of hypothetical fishing trips, and asked to identify which trips they would take. Each hypothetical trip was described in terms of six trip attributes and a cost per day. Hypothetical trip attributes were derived from historical means and pretest discussions with recreational fishers. The cost per day was identified as the sum of sportfishing related costs such as tackle and bait purchased specifically for the trip, charter/guide fees, and trip specific transportation costs such as auto and boat fuel. Respondents were offered trips at one of three cost levels $(\$ 100, \$ 170$, or $\$ 240$ per day). The six non-pecuniary trip attributes were: one of four halibut catch (keep and release) levels (0, 2, 4, 6 fish per trip); one of four average halibut weights (0,20, 40, $80 \mathrm{lbs}$ per fish); one of three chinook catch levels $(0,1,2$ fish per trip); one of four average chinook weights $(0,15,25,50 \mathrm{lbs}$ per fish); one of four coho catch levels $(0,2,4,6$ fish per trip); and one of two average coho weights $(0,7 \mathrm{lbs}$ per fish). Trip-by-trip preferences were elicited through a binary choice variable that indicated whether the respondent would take a particular hypothetical trip. The advantage of this approach is that it is possible to construct an experimental design that allows for substitution and complementary effects across attributes, and for the possibility of nonlinear marginal utility. While these types of effects are predicted by economic theory, they are difficult to identify in empirical studies of actual trips because attributes are often highly collinear or lack sufficient variation. Based on projected survey returns and the need to conserve degrees of freedom, nine three-trip blocks (27 unique trips) werẹ selected for use in the survey. The blocks of hypothetical trips were selected to maximize the information content of the responses using the D-optimality criterion. Each of the 4,000 survey recipients was randomly assigned one of the nine blocks of three hypothetical trips.

The participation decision, constructed using a random utility modeling framework, was modeled as a nonlinear function to allow for non-constant marginal utility, substitution, and complementarity across species:

$$
\begin{aligned}
& y_{i t}^{*}=\alpha_{0}+\alpha_{1} P_{t}+w_{t}^{T} \beta w_{t}+n_{t}^{T} \lambda n_{t}+z_{t}^{T} \gamma
\end{aligned}
$$

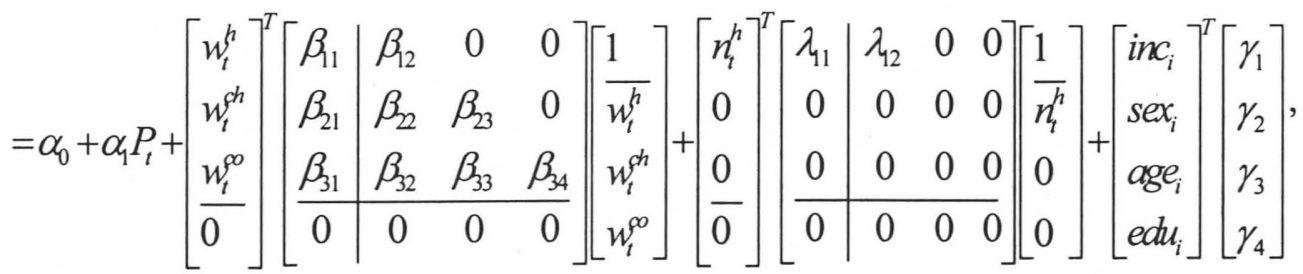


where the binary variable $y_{i t}^{*}$ was assigned a value of 1 when survey respondent $i$ indicated that she would take trip $t$ and 0 otherwise; $P_{t}, n_{t}^{s}$, and $w_{t}^{s}$, are hypothetical attributes that denote the total cost of taking trip $t$ and the number and total weight of species $s$ caught on trip $t$, respectively; halibut, chinook, and coho are denoted $h, c h$, and co, respectively; and, $i n c_{i}, \operatorname{sex}_{i}, a g e_{i}$, and $e d u_{i}$ are the household income, gender, age, and education level reported by individual $i$. The coefficient matrices $\alpha$, $\beta, \lambda$, and $\gamma$, and a random effects parameter $\rho$ were estimated simultaneously for resident and nonresident respondents using a random effects probit procedure. The data and coefficient matrices are partitioned to emphasize components responsible for representing linear and quadratic factors. To ensure that the participation decisions were grounded in recent experience, coefficient estimation was based on the 352 surveys returned by respondents who took at least one salmon or halibut sportfishing trip in marine waters off the Kenai Peninsula during 1997. Each respondent answered questions regarding three different hypothetical trips, yielding a total of 1,056 observations.

Coefficient estimates are reported in Table 5. The random effect parameter, $\rho$, is statistically different from zero at the $99 \%$ level ( $p=0.0057$ ), confirming the presence of a random effect. The point estimates of the parameters accord well with economic theory: the price coefficient is negative; the coefficients on total halibut, chinook salmon, and coho salmon weights and halibut catches are positive; coefficients on the quadratic terms and cross products are negative, implying that recreational fishers experience decreasing marginal utility and that catches of each species are substitutes for catches of the others; and, the probability of taking a trip increases as a function of income, age, and education, and is higher for males. Overall model performance was good: the log likelihood at convergence is -542.503 and -731.047 when the parameters were set to zero; and $R^{2}$ is $0.442 .^{1}$

The conditional individual participation probabilities are aggregated into estimates of total demand using a simulation-based sample enumeration method that takes into account differences in demographic characteristics and variability in the number of days fished per year by developing forecasts for each individual in the sample (see e.g., BenAkiva and Lerman 1987). Because the point estimates of percentage changes in the number of sportfishing-days are highly nonlinear, a Monte Carlo procedure based on 10,000 draws was used to estimate $90 \%$ confidence intervals (see e.g., Krinsky and Robb 1996). Following Hanemann (1999), conditional estimates of angler welfare were calculated from the estimated participation rate model as the product of the weighted average compensating variation per trip taken and the total number of angler-days spent fishing for salmon and halibut in Lower or Central Cook Inlet. (See Herrmann et al. (2001a) for a detailed development of these estimates.) The estimated average daily compensating variation is $\$ 80.83$ for Alaskans and $\$ 118.88$ for nonresidents (Table 6). Total compensating variation is $\$ 19.2$ million ( $\$ 10.3$ million for nonresidents and $\$ 8.9$ million for residents). Every change that affects sportfishing trip attributes affects the average sport fisher's decision to participate, regardless of whether the attribute change is due to changes in the cost of a sportfishing trip, natural population fluctuations, regulatory change, or environmental damage. Changes in the probability of individual participation lead to shifts in the total demand for sportfishing trips and to changes in angler welfare.

\footnotetext{
${ }^{1}$ The log-likelihood at convergence is the value of the log-likelihood function evaluated at the parameter values we report. These are the parameter values that maximize the log-likelihood function and were found by using a numerical optimization algorithm. Our estimate of $R^{2}$ follows Veall and Zimmerman (1996): 


\section{Regional Impact Analysis}

While economic efficiency (i.e., consumer surplus for anglers and producer surplus for charter operators) is a standard objective identified by economists, the Magnuson-Stevens Act places importance on both efficiency and equity issues when managing the nation's fisheries (US Department of Commerce 1996). Recent litigations involving fisheries have also stressed distributional issues (e.g., Northern Economics 1990, MAP 1992, Cohen 1993). Economic impact analysis provides a snapshot of the economic interdependencies of various industries in a regional economy, and therefore allows analysts to model the downstream effects of demand changes for commodities or services. Since opportunity costs and willingness to pay do not enter into the impact assessment framework, the results of an economic impact analysis should not be confused with statements of value. It should be noted, however, that the results that yield the greatest value under a net benefit analysis might at times imply very disproportional allocations among stakeholders. Because notions of fairness and equity do not enter into the standard net benefits framework, economic impact analyses are useful tools for tracking and identifying impacts, in revenue, income and employment terms, of alternative policies. For a more detailed discussion on the differences and appropriate uses of cost-benefit and economic impact analyses, see Edwards (1990) and Steinback (1999).

To model the regional impact of the sports fishery on the Kenai Peninsula we selected IMPLAN. (Olson and Lindall 1997), the most commonly used I-O model, as a base for our model. IMPLAN includes 21 economic and demographic variables for 528 industrial sectors for all US counties (and boroughs). Although the national level data are regularly updated, these updates are not necessarily apportioned accurately across the various regional data sets. Moreover, regions may have unique economic sectors or linkages that are not well represented in IMPLAN. Consequently, in regions such as Alaska, where the small numbers of firms creates frequent disclosure problems, and where the economy is rapidly evolving and heavily resource dependent, it is particularly essential that the transaction coefficients be thoroughly updated and carefully groundtruthed with local data and expert knowledge.

Because the sportfishing sector is not explicitly represented in IMPLAN, we developed a programming module that disaggregates IMPLAN sectors that include recreation related activities to identify those activities generated by sportfishing. This module utilizes IMPLAN generated response coefficients and secondary regional economic data as inputs in model formulation. The secondary model data is augmented with data for the target sectors (e.g., sport/charter industry) supplied by primary data collection. Thus the sportfishing module, through its I-O framework, explicitly accounts for linkages between various economic sectors, according to production and consumption patterns. (See Hermann et al. 2001a for a detailed description of the development of this model.)

In contrast to manufacturing sectors, which are well represented in IMPLAN, retail sectors are highly aggregated. Bushnell and Hyle (1985), Wolsky (1984), and Gillen and Guccione (1990) suggest approaches that directly modify the technical coefficients matrix. This requires reprogramming of IMPLAN's social accounting matrices to reflect the characteristics of the disaggregated subsector. By including the new sector within the model, the changes are noted within the use (absorption), byproducts, and final demand matrices. Regional purchase coefficients and value added features are likewise constructed for the new sector. We used the first approach to represent charter operations and the second to represent expenditures by sport fishers.

Individual sportfishing activities are accommodated differently from direct income generating activities such as guiding, harvesting, and processing. Individual sportfishing activities are accounted for by expenditure patterns in retail and service sectors, rather than treated as an identifiable economic sector. The recreational fishing module allocates recreational expenditures among these sectors. A model of the average charter operation's purchasing pattern was constructed using data obtained by NPFMC (2000) as well as discussions with local experts and members of industry during fieldwork conducted for this study. Standard Industrial Classification codes for the corresponding inputs were translated to the IMPLAN sectoral scheme and a production function was estimated for the 1997 charter sector sales value of $\$ 13.6$

million. (For a detailed accounting of the individual expense categories, corresponding Standard 
Industrial Classification codes and translation to the IMPLAN sectoral scheme, the reader is referred to Herrmann et al. 2001a). For the other expenditure categories impact scenarios were run in IMPLAN to generated response coefficients. These response coefficients and those developed for the charter sector were linked in a stand-alone recreational module (Hamel et al. 2001).

\section{Simulation Results and Analysis}

The integrated model can be used to explore the effect of variation in trip attributes on angler welfare and regional economic activity. Although the model was developed, in part, to meet the needs of environmental and regulatory impact analyses related to outer continental shelf minerals exploration, development and production activities in the Cook Inlet Planning Area (Herrmann et al. 2001a), preliminary model results have also been used in regulatory analyses related to recent management actions designed to constrain the expansion of charter-based sportfishing for halibut and analyses related to the possible adoption of individual fishing quotas for charter-based halibut catches (NPFMC 2000, 2001).

Changes in the probability that the average sport fisher will take a trip are estimated using the parameter estimated from the probit model and aggregated into predictions of changes in total sportfishing effort and used to predict changes in angler welfare and regional economic impacts. Figure 2 depicts changes in the probability that an average sport fisher would take a sportfishing trip as a function of percentage changes in the expected catch of halibut. The changes in participation show a declining marginal utility of catch and that Alaskans are more sensitive than nonresidents to changes in expected catch. Reductions (increases) in expected catch reduce (increase) the compensating variation in two ways. First, the marginal sport fisher will drop out (enter) of the fishery as the expected benefits (in terms of catch) decrease (increase), thereby decreasing (increasing) the total net benefits of the fishery. Second, the net benefit of taking a trip is also reduced (increased) for all the sport fishers who continue to participate because each trip produces less (more) net benefit when the catch rate declines (increases).

The relationship between total angler welfare and changes in catch is represented in Figure 3. The total net benefits that accrue to Alaskan anglers are more responsive to changes in expected catch than are those obtained by nonresidents. Nevertheless, a 30\% reduction in expected catch would reduce total compensating variation to about one-half the 1997 resident and nonresident baseline levels. Resident and nonresident angler net benefits alike would be all but eliminated if the expected catch fell by more than $50 \%$. Changes in halibut abundance or management policies that increase expected halibut catch-per-day by $30 \%$ could be expected to increase angler net benefits by $\$ 5.8$ and $\$ 3.6$ million for residents and nonresidents, respectively.

Unlike angler net benefits, which are a measure of economic efficiency, impact analysis is a measure of distribution. That is, changes in average daily compensating variation affect regional economic activity when they lead to changes in the total number of sportfishing-days. Furthermore, the net regional impact is limited to those recreators who do not substitute other types of expenditures on the Kenai Peninsula in lieu of expenditures that they would have made if they had gone fishing. Assessment of the regional economic impacts of marine sportfishing on the Kenai Peninsula Borough begins with a baseline of expenditures that fluctuates as sport fisher behavior responds to changes in fishing conditions. Table 4 breaks out the $\$ 25$ million of "new" money to the region spent by non-local Alaskans and nonresidents ( $\$ 15.3$ million of fishing related expenses and $\$ 9.7$ million of other expenses). Changes in expected angler success (catch) affect participation decisions and, consequently, angler expenditures, industry output, personal income, and employment. The magnitude of these effects are reported in Table 7 and represented in Figures 4-7. The results indicate, for example, that for a 10\% decrease in expected halibut catches, net benefits to resident and nonresident sport fishers will decrease by $\$ 3.7$ million. The regional impacts include a $\$ 2.1$ million decrease of direct, indirect, and induced output expenditures in the Kenai Peninsula region, which will result in a decrease of $\$ 0.9$ million in personal expenditures and a loss of 59 jobs. For a $10 \%$ increase in expected halibut catch-per-day, net benefits to sport fishers will increase by $\$ 3.5$ million and there will be a $\$ 1.5$ million increase of direct, indirect, and induced output expenditures 
in the Kenai Peninsula region, which will result in an increase of $\$ 0.6$ million in personal expenditures and an increase of 44 jobs. In the case of all impacts, the higher the catch rates the smaller the marginal change in impact. This is due to the fact that there is a declining marginal value of additional fish catches and, therefore, the change in participation rates diminishes as the catch rates increase and vice versa.

Angler net benefits and regional economic impacts are also affected by changes in trip costs. Trip costs might increase as a result of increased license fees, as an unintended consequence of management actions taken to limit halibut sportfishing catches, or other changes in the supply of or demand for trips. Figure 8 illustrates that the number of angler-days fished by Alaskans is more sensitive to trip cost increases than is the number of angler-days fished by nonresidents. Consequently, if fishery managers seek to limit sportfishing catches through an equal increase in resident and nonresident license fees, the percent reduction in trips taken by Alaskans will be larger than the percent reduction in trips taken by nonresidents. Alternatively, if managers wanted to achieve identical percent reductions in resident and nonresident trips, they could impose a larger fee increase on nonresidents than they impose on residents. Moreover, if managers were strictly concerned with benefits to Alaskan resident anglers and were concerned that the imposition of a binding GHL might lead to increases in the cost of charter trips, they could select a nonresident license fee that would induce a reduction in nonresident demand sufficient to choke off any upward pressure on charter trip prices. It should be noted that such fees would need to be based on the number of days fished or the number of fish caught. No such fees currently exist for halibut sportfishing in Alaska and the authors do not necessarily advocate the creation of such fees. The regional economic impacts of changes in trip costs are reported in Table 8 and Figures 9-11. Note that although participation is a linear function of trip cost, angler welfare and regional economic activity are nonlinear. The results indicate, for example, that for a $\$ 10$ increase in expected trip costs, the number of angler-days fished will decline by 7,174 , net benefits to sport fishers will decrease by $\$ 2.2$ million, sportfishing related expenditures in the Kenai Peninsula region will fall by $\$ 1.2$ million, Kenai Peninsula Borough personal income will decline by $\$ 0.5$ million, and there will be a loss of 33 jobs.

In the participation model, when estimating the changes in the probability that individual fishers would take a trip, given varying trip attributes, it is assumed that the price of the trip will remain constant at $P$. In other words, we assume that supply is perfectly elastic. While this assumption is appropriate for shore and private trips, it is probably not entirely accurate for the charter sector. To the extent that charter trips make up a sizeable portion of sportfishing effort, and to the extent that charter trips do not exhibit perfectly elastic supply curves, there may be price adjustment especially in the short-run. For example, charter operators might respond to a short-run change in expected catches by lowering their prices and keeping their customer base rather than holding prices constant and losing customers as assumed in our model. While our assumption is valid in the long run, it may be somewhat unrealistic in the short run. (If there is an upward sloping supply curve for charters then there would still be a loss in surplus associated with the charter industry when there is an environmental change; however, some of the surplus would come from producers instead of the consumers.) Additionally, if price were lowered to maintain the current level of participation, there would be little regional impact outside of fish processing. Therefore, for the charter industry, our results more closely reflect long-run results than short-run results especially with respect to income distribution. For shore and private vessels this is not a factor.

\section{Conclusions}

This study develops estimates of the net economic benefits that accrue to participants in the Lower and Central Cook Inlet halibut sport fisheries, the relationship between catch, size of catch, and the number of sportfishing days, and the regional (Kenai Peninsula area) economic impact of changes in the annual total number of person-days fished. The integrated model is used to explore changes in net benefits and changes in regional impacts associated with changes in trip costs and angler success. Changes in expected catch could result from predictable changes in stock abundance, conditionally predictable environmental damages resulting from minerals exploration, development, production, or transportation activities, or from controllable management actions that affect the allocation between commercial, subsistence, and 
sport fishers, bag and possession limits, fishing methods, or other measures that affect average catches. Changes in cost might arise as a result of predictable shifts in the demand for sportfishing, as the result of deliberate management actions such as changes in resident or nonresident license fees, stamps or endorsements, or incidental to management actions such as the GHL or charter IFQ which may affect the supply or character of sportfishing trips.

The advantage of our integrated model is that changes in participation are determined by variables that are observable, predictable, or subject to management control; that nonlinear preferences are easily accommodated; that aggregation of the individual participation probabilities provides a method for estimating angler welfare; and, that estimated changes in aggregate participation can be linked to a regional input-output model to provide estimates of the regional economic impacts of changes in trip attributes. Although the model was developed, in part, to meet the needs of environmental and regulatory impact analyses related to outer continental shelf minerals exploration, development and production activities in the Cook Inlet Planning Area (Herrmann et al. 2001a), preliminary model results have also been used in regulatory analyses related to recent management actions designed to constrain the uncompensated reallocation of halibut from the commercial fishery to the charter-based sport fishery (NPFMC 2000, 2001).

\section{References}

Aas, O. 1995. Constraints on sportfishing and effect of management actions to increase participation rates in fishing. North American Journal of Fisheries Management 15: 631-638.

BenAkiva, M., and S.R. Lerman. 1985. Discrete choice analysis: Theory and applications to travel demand. MIT Press, Cambridge, MA.

Bushnell, R.C., and M. Hyle. 1985. Computerized models for assessing the economic impact of recreation and tourism. In D.B. Probst, editor, Assessing the economic impacts of recreation and tourism. Southeastern Forest Experiment Station, Asheville, NC.

Cohen, M.J. 1993. Economic aspects of technological accidents: an evaluation of the Exxon Valdez oil spill on Southeastern Alaska. Ph.D. Dissertation, University of Pennsylvania.

Edwards, S.F. 1994. An economic guide to allocation of fish stocks between commercial and recreational fisheries. NOAA Technical Report. National Marine Fisheries Service.

Gillen, W.J. and A. Guccione. 1990. Disaggregating input-output models; an alternative to Wolsky's method. Economic Systems Research 2: 39-42.

Hamel, C., M. Herrmann, S.T. Lee, and K.R. Criddle. 2001. An economic assessment of Lower and Central Cook Inlet sport fisheries: software program and manual. Developed for Minerals Management Service / University of Alaska Coastal Marine Institute, Fairbanks, AK.

Hanemann, M.W. 1999. Welfare analysis with discrete choice variables. In J. A. Herriges and C. L. Kling (editors), Valuing recreation and the environment: revealed preference methods in theory and practice. Edward Elgar, Northampton, ME.

Herrmann, M., S.T. Lee, C. Hamel, and K.R. Criddle. 2001a. An economic assessment of the sport fisheries for halibut, chinook and coho salmon in Lower and Central Cook Inlet. Final Report, project 12-35-0001-30661 task order 14196, Mineral Management Service-University of Alaska Coastal Marine Institute, Fairbanks, AK.

Herrmann, M., S.T. Lee, K.R. Criddle, and C. Hamel. 2001b. A survey of participants in the Lower and Central Cook Inlet halibut and salmon sport fisheries. Alaska Fishery Research Bulletin 8: xxx-xxx.

Holland, S.M., and R.B. Ditton. 1992. Fishing trip satisfaction: a typology of anglers. North American Journal of Fisheries Management 12: 28-33.

Howe, A.L., G. Fidler, C. Olnes, A.E. Bingham, and M.J. Mills. 1998. Harvest, catch, and participation in Alaska sport fisheries during 1997. Alaska Department of Fish and Game, Fishery Data Series No. 98-25, Anchorage, AK.

Krinsky, I., and A.L. Robb. 1986. On approximating the statistical properties of elasticities. Review of Economic Statistics 9: 715-719.

MAP (Marine Advisory Program). 1992. After the Exxon Oil Spill. Alaska's Marine Resources. University of Alaska Sea Grant College Program, Fairbanks, AK.

NPFMC (North Pacific Fishery Management Council). 2000. Draft environmental assessment/regulatory impact review/initial regulatory flexibility analysis for a regulatory amendment to implement management measures under a guideline harvest level and/or moratorium for halibut in areas 2C and 3A. North Pacific Fishery Management Council, Anchorage, AK.

NPFMC (North Pacific Fishery Management Council). 2001. Draft environmental assessment/regulatory impact review/initial regulatory flexibility analysis for a regulatory amendment to incorporate the halibut charter sector into the halibut individual fishing quota program or implement a moratorium on entry into the charter fleet for Pacific halibut in Areas $2 \mathrm{C}$ and $3 \mathrm{~A}$. North Pacific Fishery Management Council, Anchorage, AK. 
Northern Economics. 1990. Economic impacts of the S.S. Glacier Bay oil spill. U.S. Minerals Management Service, Alaska Outer Continental Shelf Region, Anchorage, AK.

Olson, D., and S. Lindall. 1997. IMPLAN professional software, analysis, and data guide. Minnesota IMPLAN Group, Stillwater, $\mathrm{MN}$.

Steinback, S.R. 1999. Regional economic impact assessments of recreational fisheries: an application of the IMPLAN modeling system to marine party and charter boat fishing in Maine. North American Journal of Fisheries Management 19: $725-736$.

Thunberg, E., S.R. Steinback, G. Gray, A. Gautam, M. Osborn. 1999. Summary report of methods and descriptive statistics for the 1994 northeast region marine recreational fishing participation survey, NOAA Technical Memorandum NMFSF/SPO39.

U.S. Department of Commerce. 1996. Magnuson-Stevens fishery conservation act. NOAA Technical Memorandum NMFSF/SPO-23.

Veall, M.R. and K.F. Zimmermann, 1996. Pseudo- $\mathrm{R}^{2}$ measures for some common limited dependent variable models. Journal of Economic Surveys 10: 241-259.

Wolsky, A.M. 1984. Disaggregating input-output models. The Review of Economics and Statistics 66: 283-291. 


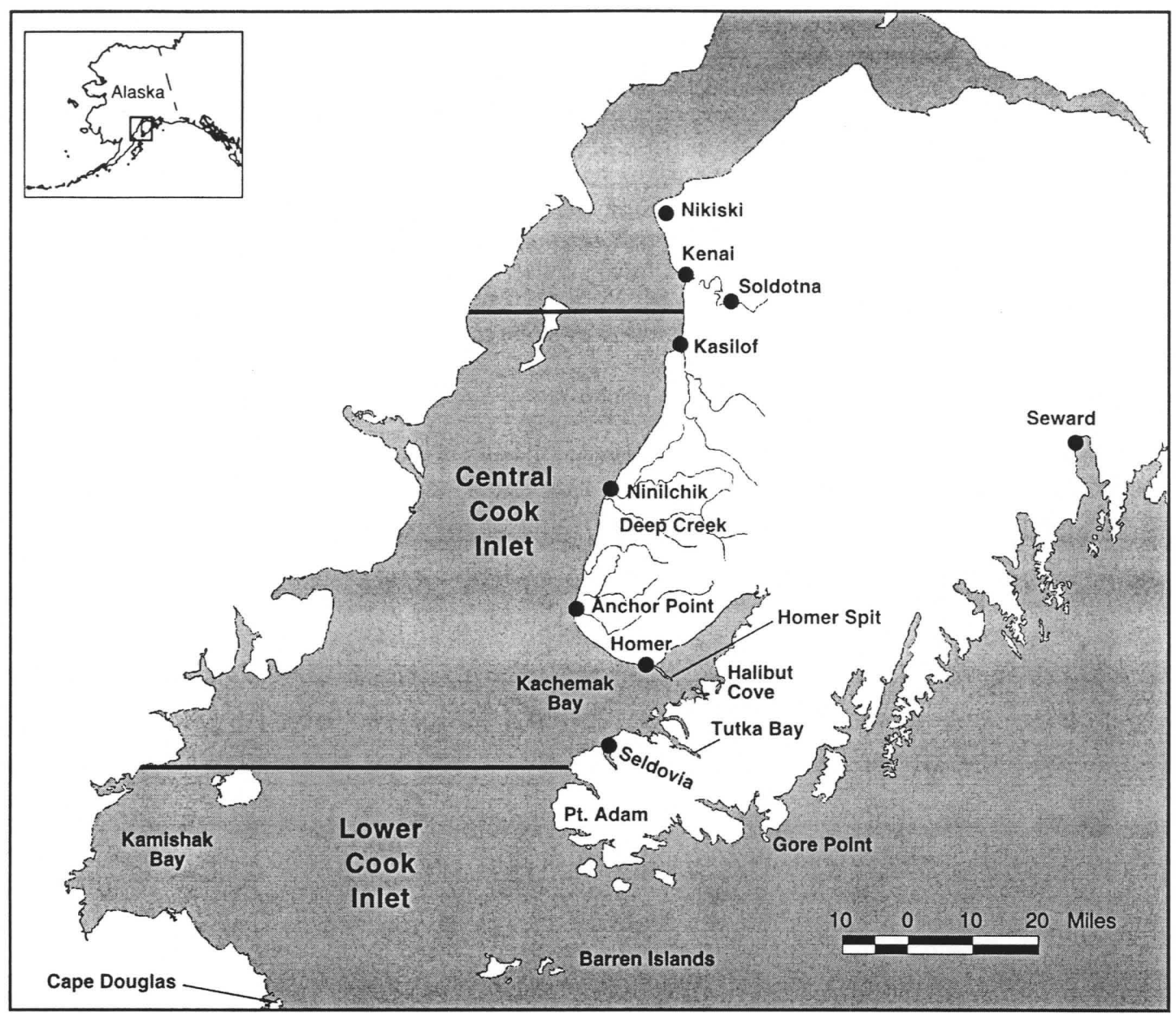

Figure 1. Cook Inlet study area. 
Alaskan Residents

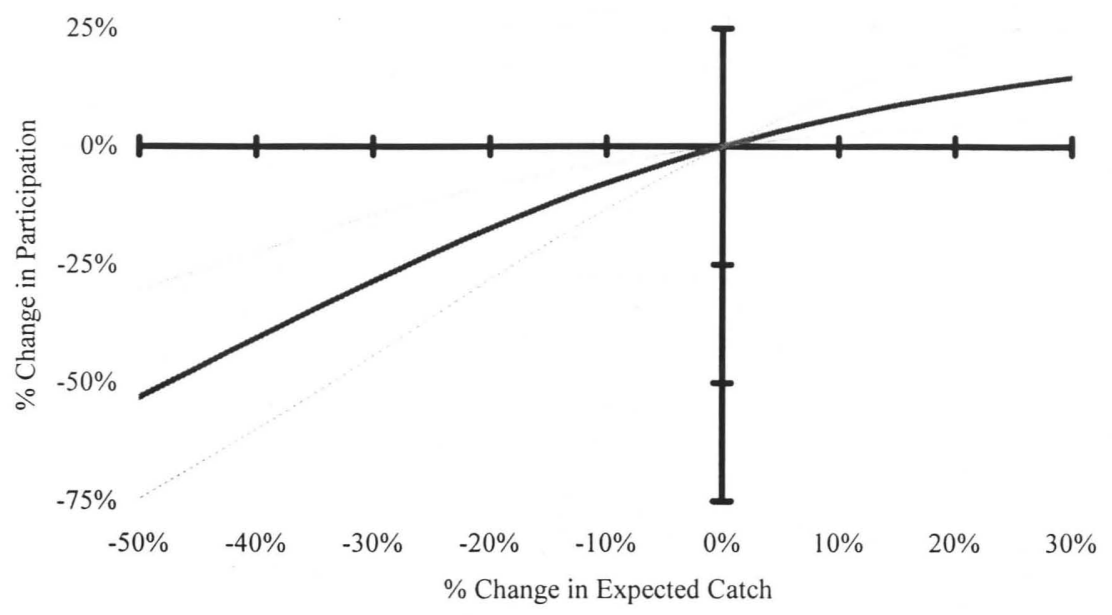

Nonresidents

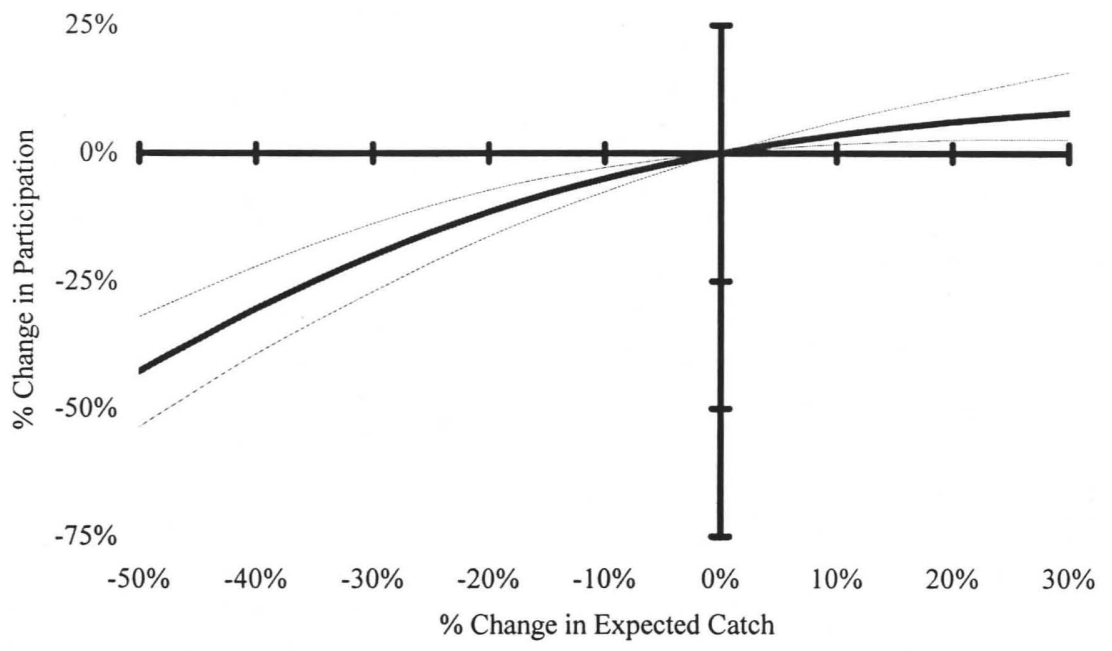

Figure 2. Percentage change in the probability that the average sport fisher will participate as a function of changes in expected halibut catch. The thick line represents the mean estimate. The thin lines represent upper and lower $90 \%$ confidence intervals. 
Alaskan Residents

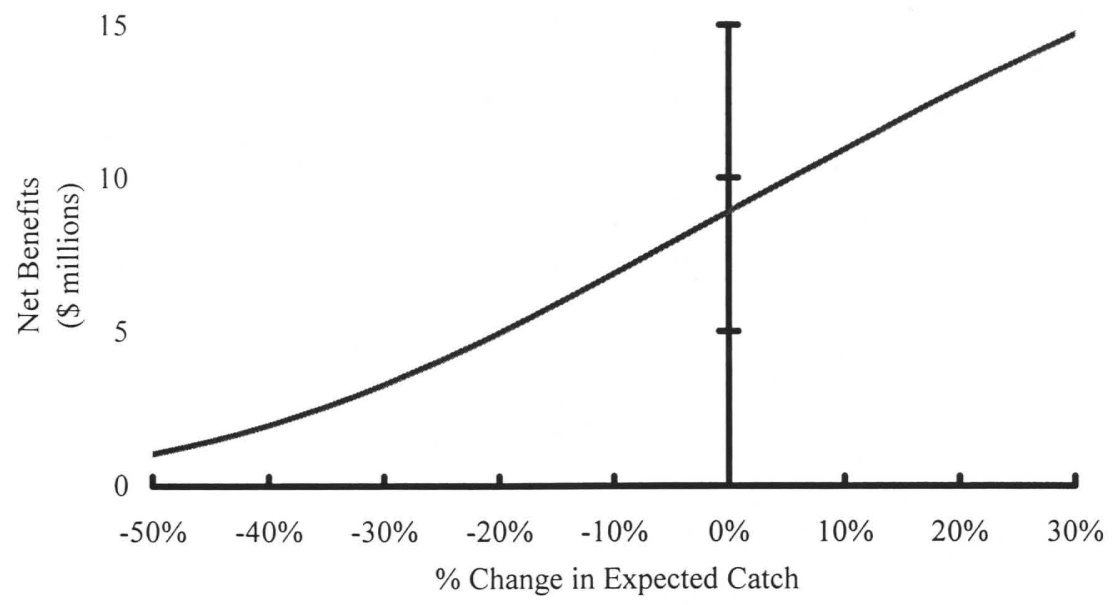

Nonresidents

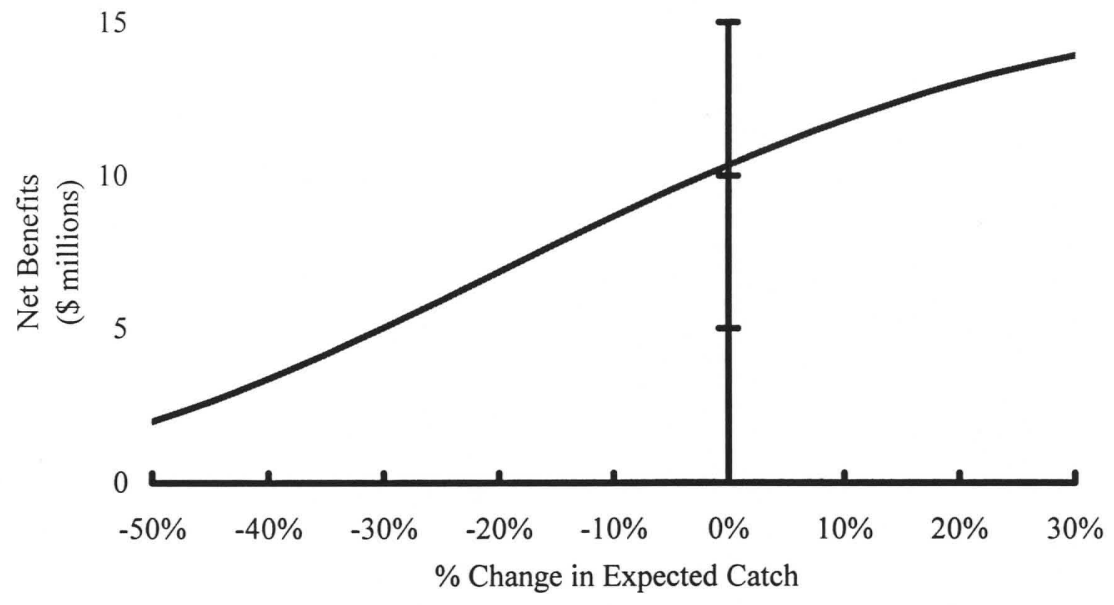

Figure 3. The effect of changes in expected halibut catch on the magnitude of total compensating variation. 


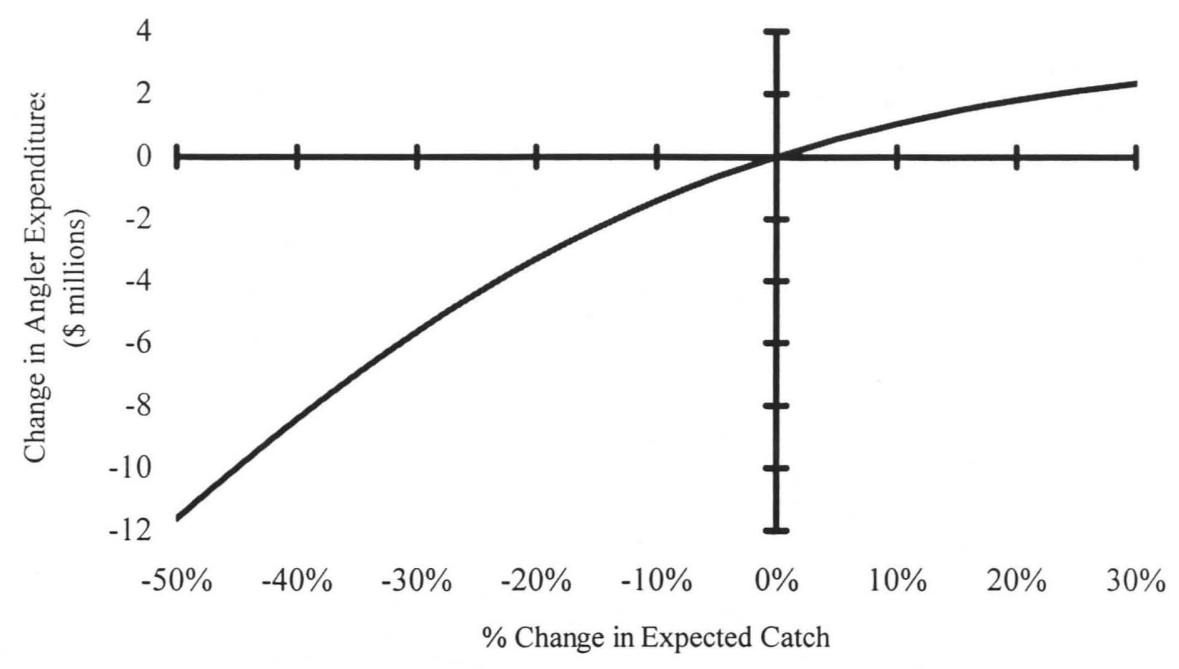

Figure 4. Changes in direct angler expenditures from changes in expected catches of halibut in the Lower and Central Cook Inlet sport fisheries.

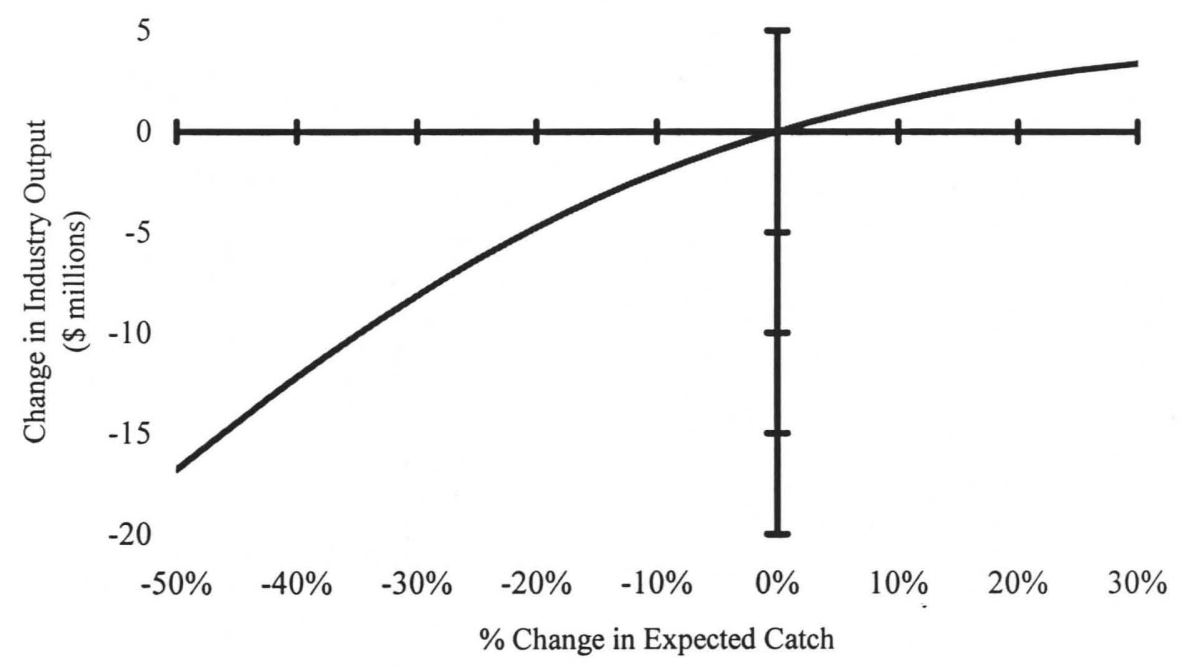

Figure 5. Industry output impacts from changes in expected catches of halibut in the Lower and Central Cook Inlet sport fisheries. 


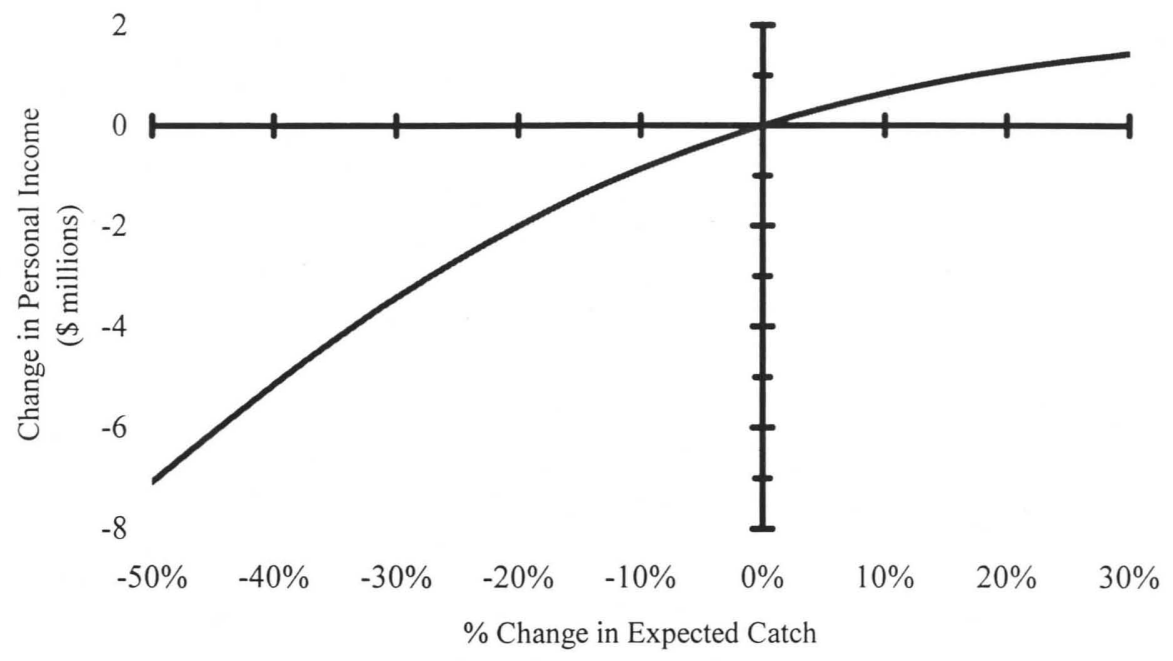

Figure 6: Personal income impacts from changes in expected catch of halibut in the Lower and Central Cook Inlet sport fisheries.

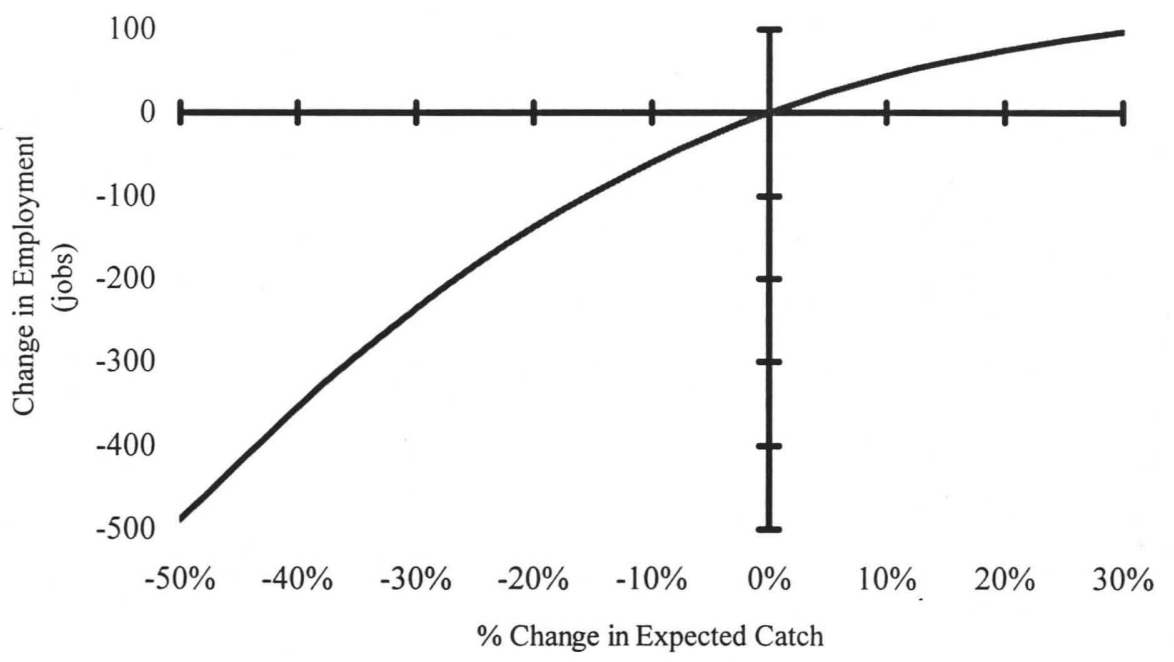

Figure 7: Employment impacts from changes in expected catch of halibut in the Lower and Central Cook Inlet sport fisheries. 


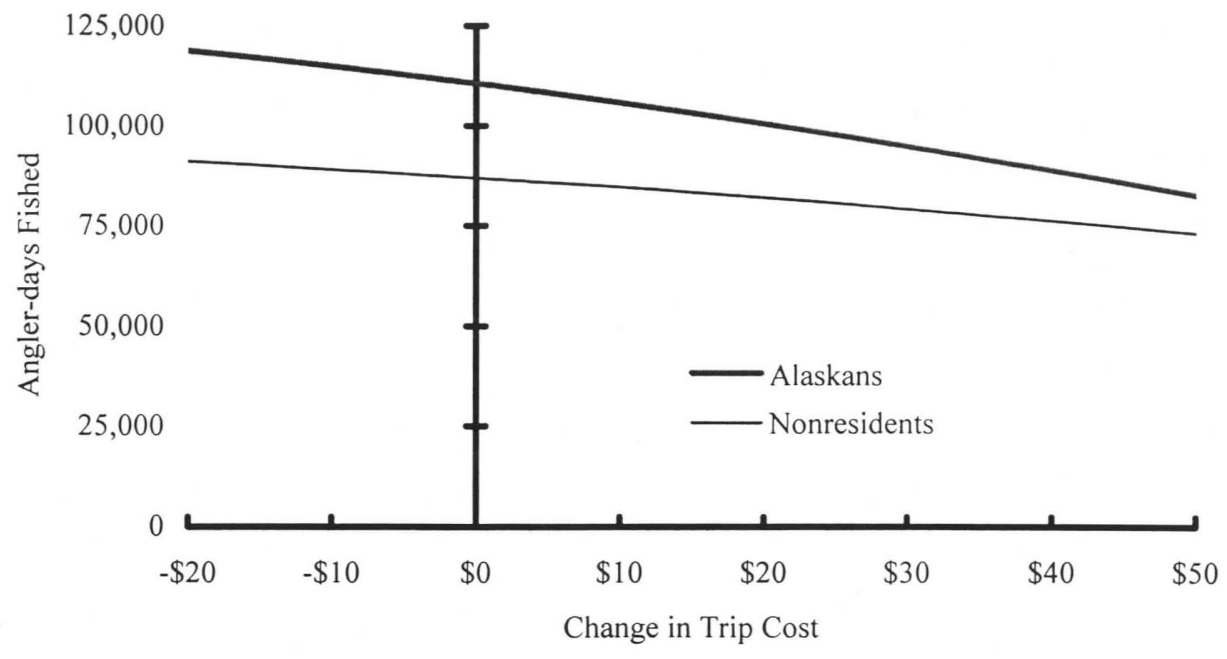

Figure 8: Change in participation as a function of changes in the average cost of a sportfishing trip in the Lower or Central Cook Inlet.

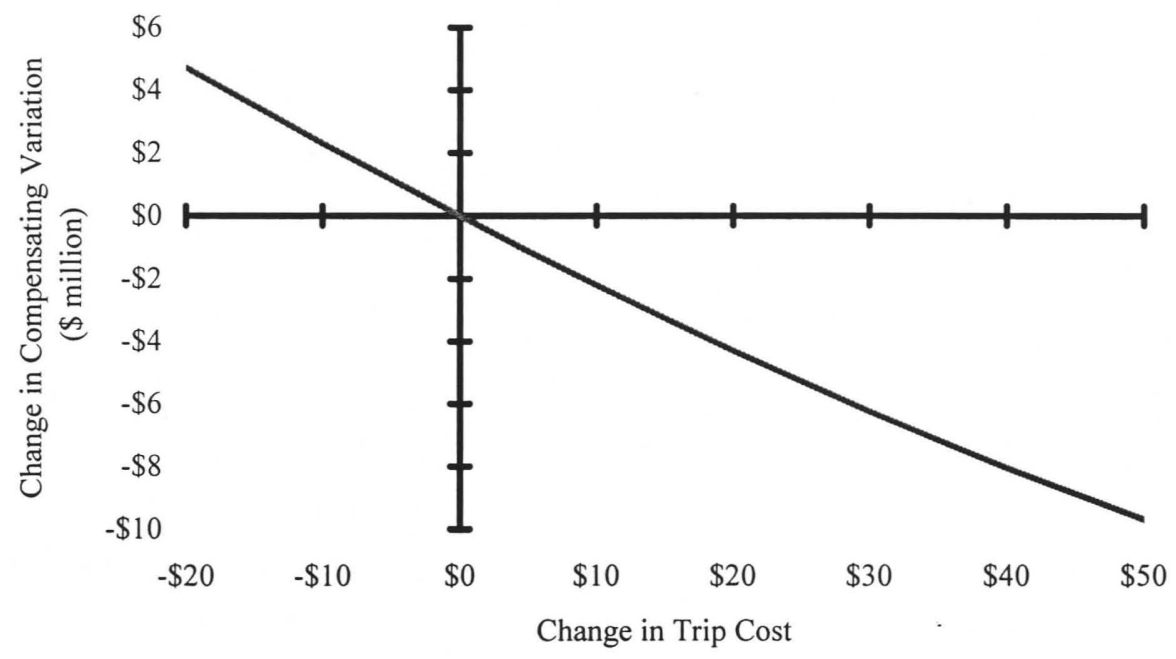

Figure 9: Change in compensating variation as a function of changes in the average cost of a sportfishing trip in the Lower or Central Cook Inlet. 


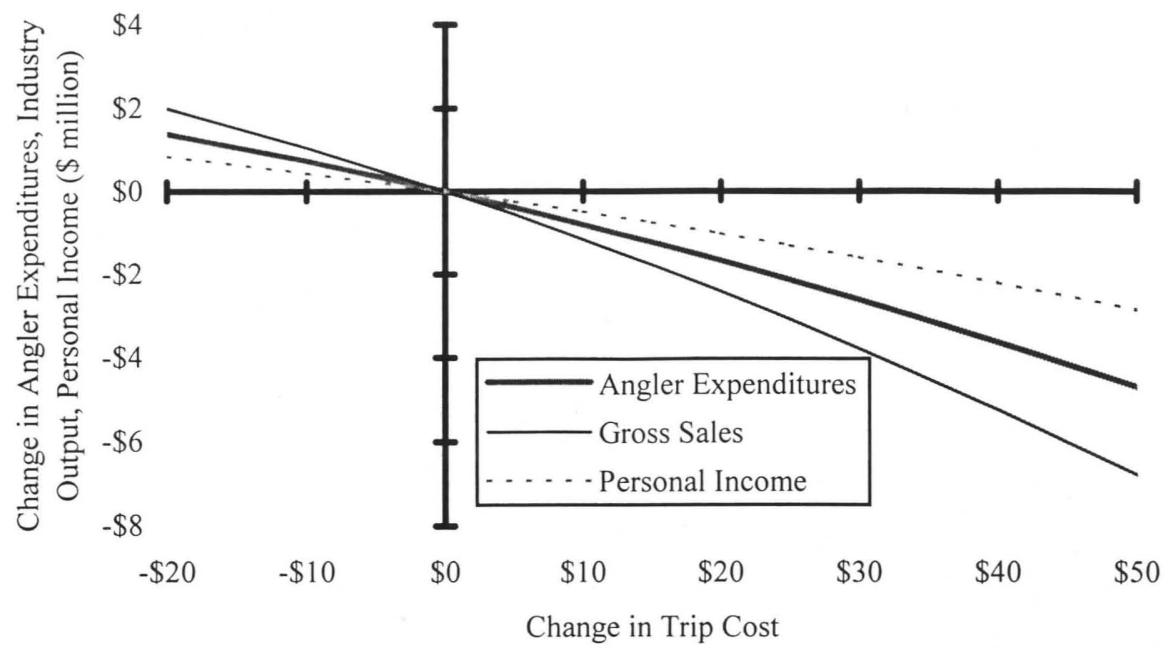

Figure 10: Change in angler expenditures, gross sales (output), and personal income as functions of changes in the average cost of a sportfishing trip in the Lower or Central Cook Inlet.

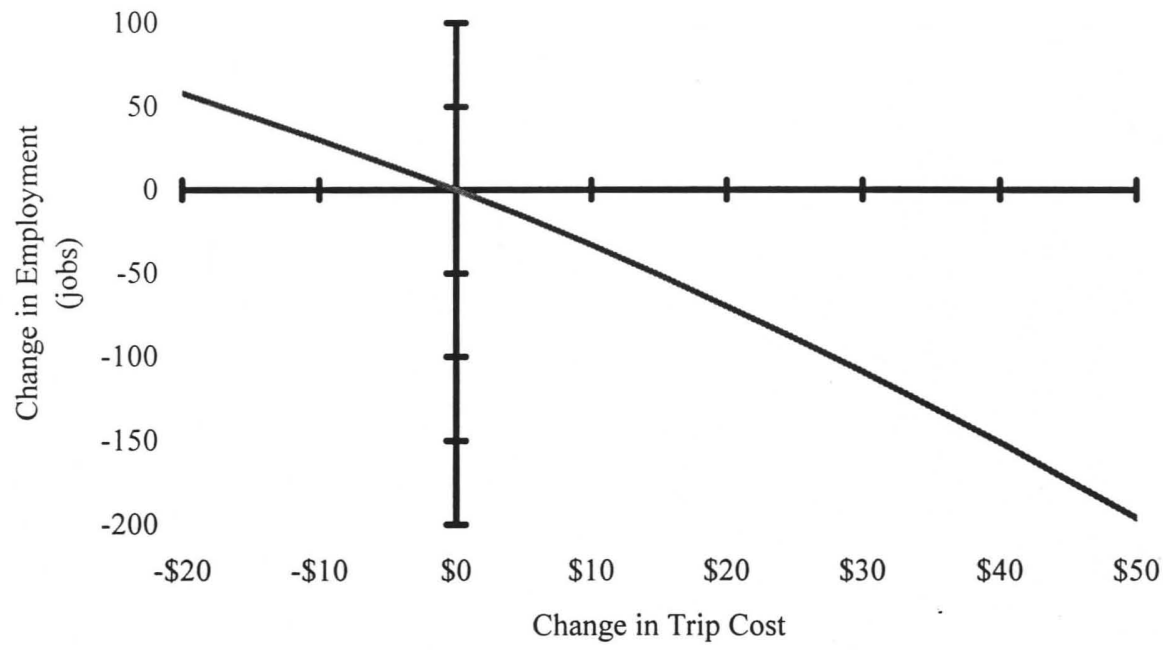

Figure 11: Change in employment as a function of changes in the average cost of a sportfishing trip in the Lower or Central Cook Inlet. 
Table 1

Effort distribution (\%) by residency category and sportfishing mode (Herrmann et al. 2001b).

\begin{tabular}{lcccc}
\hline & Charter & Private & Shore & Total \\
\hline Local & $3.8 \%$ & $14.4 \%$ & $6.5 \%$ & $24.7 \%$ \\
Alaskan (non-local) & $10.1 \%$ & $18.8 \%$ & $2.4 \%$ & $31.2 \%$ \\
Nonresident & $25.9 \%$ & $13.0 \%$ & $5.2 \%$ & $44.0 \%$ \\
Total & $39.8 \%$ & $46.1 \%$ & $14.1 \%$ & $100.0 \%$ \\
\hline
\end{tabular}

\section{Table 2}

Total expenditures by all sport fishers fishing for halibut and salmon in Lower and Central Cook Inlet that are directly attributable to the saltwater halibut and salmon fishing trip (Herrmann et al. 2001a).

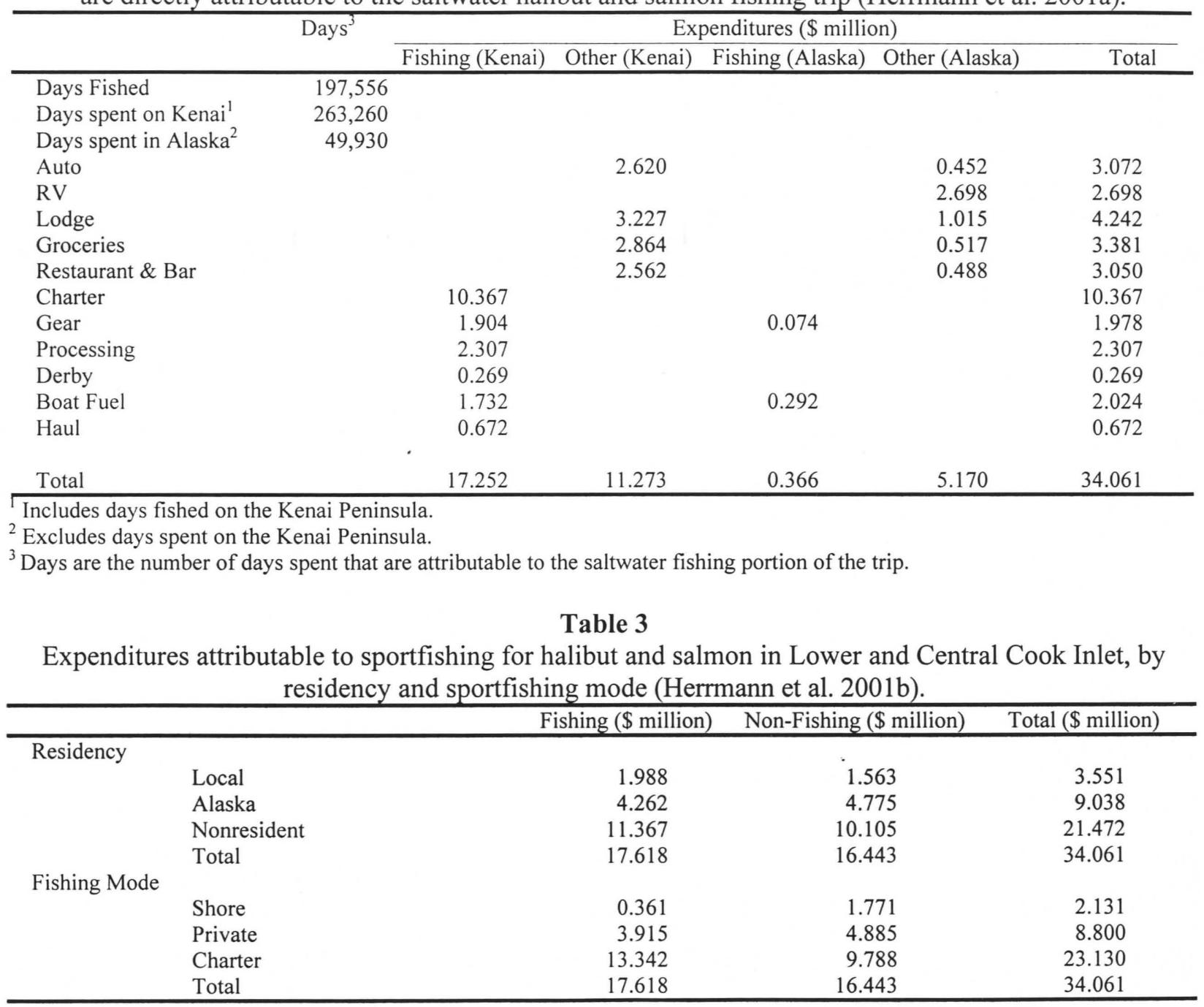


Table 4

Total Kenai Peninsula area expenditures by Alaskans (non-local) and nonresidents that can be attributed directly to Lower and Central Cook Inlet halibut or salmon sportfishing trips (Herrmann et al. 2001b).

\begin{tabular}{lcc} 
directly to Lower and Central Cook Inlet halibut or salmon sportfishing trips (Herrmann et al. 2001b). \\
\hline \multicolumn{2}{c}{$\begin{array}{c}\text { Expenditures (\$ million) } \\
\text { Other Expenditures }\end{array}$} \\
\hline Auto fuel & Fishing Expenditures & 2.208 \\
Auto/RV rentals & 0 \\
Lodge & & 3.061 \\
Groceries & & 2.443 \\
Restaurant \& Bar & & 1.997 \\
Charter & 9.518 & \\
Gear & 1.659 & 2.202 \\
Processing & 0.171 & 1.279 \\
Derby & 0.433 & 9.710 \\
Boat Fuel & & \\
Haul/moorage & 15.263 & \\
Total & & \\
\hline
\end{tabular}

Table 5

Random effects probit model parameter estimates (Herrmann et al. 2001a).

\begin{tabular}{lcccc}
\hline & Alaskans (local and non-local) & \multicolumn{2}{c}{ Nonresidents } \\
& Estimates & t-ratios & Estimates & t-ratios \\
\hline Intercept & -2.8415 & -3.03 & -1.4746 & -1.86 \\
Price & -0.0124 & -7.39 & -0.0094 & -6.96 \\
Total weight of halibut & 0.0371 & 3.30 & 0.0228 & 2.53 \\
Total weight of chinook & 0.1037 & 4.32 & 0.0732 & 3.56 \\
Total weight of coho & 0.1242 & 2.95 & 0.1163 & 3.19 \\
Squared halibut weight & -0.0001 & -2.88 & -0.0001 & -1.33 \\
Squared chinook weight & -0.0006 & -3.41 & -0.0004 & -2.52 \\
Squared coho weight & -0.0008 & -1.13 & -0.0011 & -1.82 \\
Product of total weight of halibut and coho caught & -0.0005 & -3.50 & -0.0004 & -3.20 \\
Product of total weight of halibut and chinook caught & -0.0007 & -2.84 & -0.0005 & -2.38 \\
Product of total weight of chinook and coho caught & -0.0018 & -3.60 & -0.0010 & -2.26 \\
Number of halibut caught & 1.1033 & 2.05 & 0.9241 & 2.33 \\
Squared number of halibut caught & -0.1492 & -2.19 & -0.1297 & -2.52 \\
Per-Capita Household Income & 0.0945 & 1.09 & 0.0021 & 0.04 \\
Gender (1=male) & 0.3853 & 2.03 & 0.0963 & 0.57 \\
Age & 0.0080 & 1.04 & 0.0003 & 0.05 \\
Education (1=college graduate) & 0.2827 & 1.39 & 0.3853 & 2.49 \\
$\rho$ & 0.192 & 2.77 & 0.192 & 2.77 \\
\hline
\end{tabular}

Table 6

Estimated compensating variation ${ }^{1}$.

\begin{tabular}{rrrccr}
\hline Residency Category & Angler Days & \multicolumn{3}{c}{ CV per Day (\$) } & \multicolumn{3}{c}{ Total CV (\$million) } \\
& & Mean & $90 \%$ lower bound & $90 \%$ upper bound & Mean \\
\hline Local & 48,877 & 80.83 & 45.75 & 121.63 & 3.927 \\
Alaskan & 61,709 & 80.83 & 45.75 & 121.63 & 4.957 \\
Nonresident & 86,970 & 118.88 & 84.90 & 157.22 & 10.339 \\
Total & 197,556 & & & 19.223 \\
\hline
\end{tabular}

See Herrmann et al 2001a for confidence interval calculations. 
Table 7

Changes in compensating variation (CV) and regional economic impacts in response to changes in halibut catch.

\begin{tabular}{cccccc}
\hline \% Change in Catch & $\begin{array}{c}\text { \% Change in } \\
\text { Participation }\end{array}$ & $\begin{array}{c}\text { Change in Total CV } \\
\text { (\$ million) }\end{array}$ & $\begin{array}{c}\text { Change in Output } \\
\text { (Sales) }(\$ \text { million) }\end{array}$ & $\begin{array}{c}\text { Change in Personal } \\
\text { Income (\$ million) }\end{array}$ & $\begin{array}{c}\text { Change in } \\
\text { Employment (Jobs) }\end{array}$ \\
\hline$-50 \%$ & -50.42 & -16.191 & -16.795 & -7.081 & -488 \\
$-40 \%$ & -37.36 & -13.886 & -12.210 & -5.150 & -354 \\
$-30 \%$ & -25.36 & -10.900 & -8.142 & -3.346 & -236 \\
$-20 \%$ & -15.04 & -7.424 & -4.750 & -2.005 & -137 \\
$-10 \%$ & -6.60 & -3.709 & -2.057 & -0.868 & -59 \\
$+3.51^{1}$ & 197,556 & $\$ 19.2$ & $\$ 28.5$ & $\$ 12.034$ & 822 \\
$+10 \%$ & 5.00 & 3.505 & 1.523 & 0.643 & 44 \\
$+20 \%$ & 8.69 & 6.662 & 2.260 & 1.107 & 75 \\
$+30 \%$ & 11.34 & 9.378 & 3.384 & 1.432 & 97 \\
\hline
\end{tabular}

The values reported in this row are the baseline levels and are provided to add a relative context to the absolute changes.

\section{Table 8}

Changes in days fished and regional economic impacts in response to increases in the average cost of a sportfishing trip.

\begin{tabular}{cccccc}
\hline Price & Days & $\begin{array}{c}\text { Change in Total CV } \\
(\$ \text { million) }\end{array}$ & $\begin{array}{c}\text { Change in Output } \\
\text { (Sales) }(\$ \text { million) }\end{array}$ & $\begin{array}{c}\text { Change in Personal } \\
\text { Income (\$million) }\end{array}$ & $\begin{array}{c}\text { Change in } \\
\text { Employment (Jobs) }\end{array}$ \\
\hline$\$ 173^{1}$ & 197,556 & $\$ 19.2$ & $\$ 28.5$ & $\$ 12.034$ & 822 \\
$+\$ 5$ & $-3,503$ & -1.12 & -0.56 & -0.24 & -16 \\
$+\$ 10$ & $-7,174$ & -2.21 & -1.16 & -0.49 & -33 \\
$+\$ 15$ & $-11,008$ & -3.26 & -1.78 & -0.75 & -51 \\
$+\$ 25$ & $-19,146$ & -5.28 & -3.09 & -1.31 & -89 \\
$+\$ 50$ & $-41,846$ & -9.68 & -6.78 & -2.86 & -196 \\
\hline
\end{tabular}

\footnotetext{
The values reported in this row are the baseline levels and are provided to add a relative context to the absolute changes.
} 


\title{
Participation Decisions, Angler Welfare, and the Regional Economic Impact of Sportfishing
}

\author{
Keith R. Criddle, Mark Herrmann, S. Todd Lee, Charles Hamel
}

\begin{abstract}
Data from a stated preference survey of anglers who fished in marine waters off the Kenai Peninsula, Alaska, are used to model angler participation, angler welfare, and regional economic activity. The probability of taking a sportfishing trip is represented as a nonlinear function of predictable or controllable trip attributes and demographic characteristics. Conditional individual probabilities are aggregated into estimates of total recreation demand and compensating variation using a simulation-based sample enumeration, weighted to reflect differences in participant motivation. A regionally-adjusted zip code-level input-output model is used to represent the level of primary and secondary expenditures conditioned on participation. This approach results in a behaviorally-based integrated model for exploring the changes in angler welfare and regional economic activity occasioned by changes in the demand for sportfishing that arise from changes in trip costs or the expected number, size, or mix of species caught. Because the model allows for non-linear marginal utility, and substitution and complementary effects across attributes, participation rates, angler welfare, and the magnitude of regional economic activities exhibit nonlinear responses to variations in trip attributes.
\end{abstract}

Key words Recreational demand, angler welfare, regional economic impacts

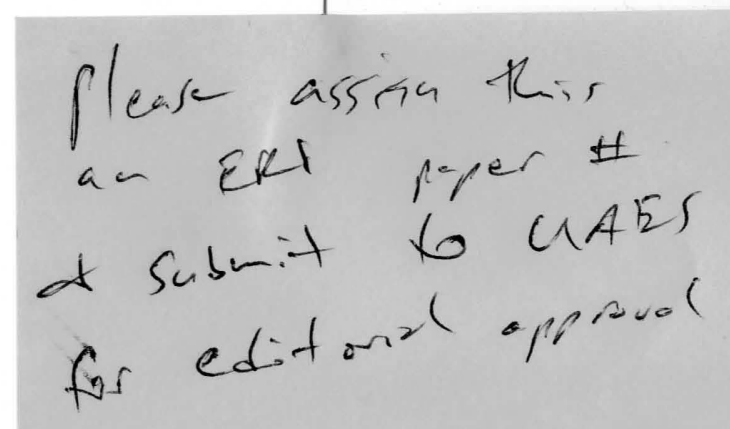

\section{Introduction}

The marine sport fisheries of Lower and Central Cook Inlet, Alaska (Figure 1), support a large recreation based economic sector that provides non-monetary benefits to participants and pecuniary benefits to businesses and residents of the Kenai Peninsula region. Although this study focuses on the region's most important saltwater sports fishery, the fishery for Pacific halibut (Hippoglossus stenolepis), the marine sport fisheries for chinook (Oncorhynchus tshawytscha) and coho (O. kisutch) are treated as potential substitutes and complements for the halibut sport fishery.

Pacific halibut are managed by an international agreement between the U.S. and Canada. Under the auspices of this agreement, the International Pacific Halibut Commission (IPHC) establishes constant exploitation yield (CEY) based harvest limits in the eastern North Pacific, Gulf of Alaska, and eastern Bering Sea. The authority to allocate catches among competing commercial, sport, and subsistence interests is delegated to the individual nations. The North Pacific Fishery Management Council (Council) is responsible for allocating halibut catches off Alaska. The commercial Total Allowable Catch (TAC) for Pacific halibut has been determined by subtracting a bycatch allowance and expected non-commercial (sport and subsistence) catches from the CEY-based harvest limit. However, as the share of halibut caught by sport fishers has increased, the Council has been lobbied to take actions to limit erosion of the commercial TAC. Growth of sportfishing catches has been particularly pronounced in the Central Gulf of Alaska Region (Prince William Sound, Resurrection Bay, Kodiak, Yakutat, and especially Cook Inlet and adjacent portions of the Gulf of Alaska) where sportfishing landings have grown from less than 2 percent of total removals (commercial, sport, and bycatch) in the late 1970's to over 18 percent in the mid 1990's.

Keith R. Criddle is a professor in the Department of Economics at Utah State University, e-mail: kcriddle@econ.usu.edu. Mark

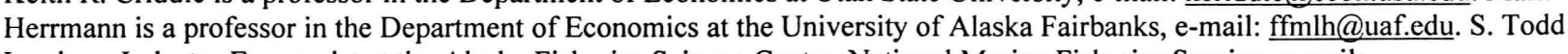
Lee is an Industry Economist at the Alaska Fisheries Science Center, National Marine Fisheries Service, e-mail:

Todd.Lee@noaa.gov. Charles Hamel is a research associate in the Department of Economics at the University of Alaska Fairbanks, e-mail: ffcdh1@uaf.edu.

Partial funding for this project was provided by the University of Alaska Sea Grant College Program project 98-403 R14-17 and from the Mineral Management Service through the University of Alaska Coastal Marine Institute project 12-35-0001-30661 task order 14196. The views expressed herein are those of the authors and do not necessarily reflect those of their respective employers or the funding entities. 